\title{
KUTATÁS
}

\author{
ILKÓ KRISZTINA
}

\section{VINCENZO DANDINI SZENT ZOERARD-ANDRÁS ÉS BORROMEO SZENT KÁROLY-OLTÁRKÉPE AZ AREZZÓI SANTA MARIA IN GRADI-TEMPLOMBAN}

\section{A bíboros és a remete}

A Piaggia di Murellótól nem messze, egy csöndes terecskén áll Arezzóban a Santa Maria in Gradi barokk kolostortemplom, pontosan az ősi Pallas-templum helyén. ${ }^{1}$ Az egyhajós tér nyugati felében, rögtön a bejárattól jobbra, Andrea Della Robbia Madonna della Misericordia hófehér mázas terrakottakompozíciójával szemben található Vincenzo Dandini (1607-1675) ${ }^{2}$ nagyméretü olajfestménye (1. kép) a Borromeo Szent Károlynak (1564-1584) szentelt mellékoltár fölött. A fal síkjába mélyedő, félköríves lezárású fülkében a 315×197 cm-es, vászonra festett, 1657-ből származó olajkép impozáns látvány. A bíborosi ruhában, pennával a kezében ülő, könnyen felismerhető, markáns arcú Borromeo Károly mellett egy másik szent fekszik a szárnyas angyal karjaiba ájultan a földön, fehér kamalduli habitusában. A passzív, ájult szentet mozdulatlanul karjában tartó angyallal éles ellentétben áll az ültében is kifejezően gesztikuláló kardinális. Az oltár alatt apró, szép kalligrafikus betűkkel kézzel írt felirat árulja el a kép címét a látogatók számára: S. Carlo Borromeo e S. Andrea Zoerardo. A kamalduli szerzetesek pontos feljegyzéseinek köszönhetően részletes információk állnak rendelkezésünkre nem csupán a kép megrendeléséről Dandinitől, hanem még a stukkódíszítés és keretezés menetéről is. A kolostortemplom historia domusából értesülünk róla, hogy a kápolnatér rendkívül igényes megformálása Jacopo Buonfiglioli kőművesmunkáját dicséri. ${ }^{3} 1658$ áprilisánál pedig maga az oltárkép megrendelése is szerepel. ${ }^{4}$ A Firenzében őrzött elszámolás szerint azonban Dandini már 1658. március 17-én megkapta a képéért járó ötszázhatvan lírát, mivel elkészítette a Borromeo Károlyt és San And- rea Zoerandrót szerepeltető oltárképet. ${ }^{5} \mathrm{~A}$ festmény megrendelöje Remigio Bucci volt, aki az apáti tisztet 1654 és 1658 között töltötte be a kolostor élén. ${ }^{6}$

Első ránézésre megdöbbentő az ábrázolás ikonográfiája, amely a képen igen zavarba ejtően egymás mellett vonultatja fel az ismert, előkelő családból származó és fényes egyházi karriert befutott itáliai bíborost és az Olaszországban szinte teljesen ismeretlen, magyarországi remetét. Szent Zoerard-András egyike volt a két zoborhegyi remetének, akik Szent István király uralkodása idején éltek, majd a Szent László által kezdeményezett, 1083-as, első magyarországi kanonizáció során elsőként vétettek fel a szentek sorába. ${ }^{7}$ Viszonylagos ismeretlensége számos félreértést eredményezett: egy 1744-es művészéletrajz-gyűjtemény az oltárképet $\mathrm{S}$. Carlo Borromeo e San Pietro (sic!) Zoerardo-ként említi, egy 19. század eleji arezzói útikalauz pedig - már szinte zoroasztriánus, misztikus tanokat sejtető félreértéssel - így emlékezik meg a képről: Vincenzo Dandini dipinse con somma intelligenza il Sant' Andrea Zoroastro. ${ }^{8}$ Ezenfelül sem Zoerard-András, sem Károly nem volt kamalduli szerzetes; míg az előbbi bencés volt a zoborhegyi apátsághoz kötődve, Károly az aronai bencés monostor kommendátor apáti címét viselte tizenkét éves korától kezdve. ${ }^{9}$ Tanulmányom mozgatórugója választ találni arra a kérdésre, hogy az arezzói szerzetesek miért éppen e két szentet választották tiszteletük tárgyául?

A magyar művészettörténet-írás ez idáig - néhány tanulmány kivételével - nem foglalkozott érdemlegesen a középkorban főként Magyarország északi régióiban jelentős kultusszal rendelkező Szent Zoerard-András ábrázolásaival. ${ }^{10}$ Dandini festményét a hazai szakirodalomban csupán Florio Banfi említi, ő is mindössze egyetlen mondatban, 


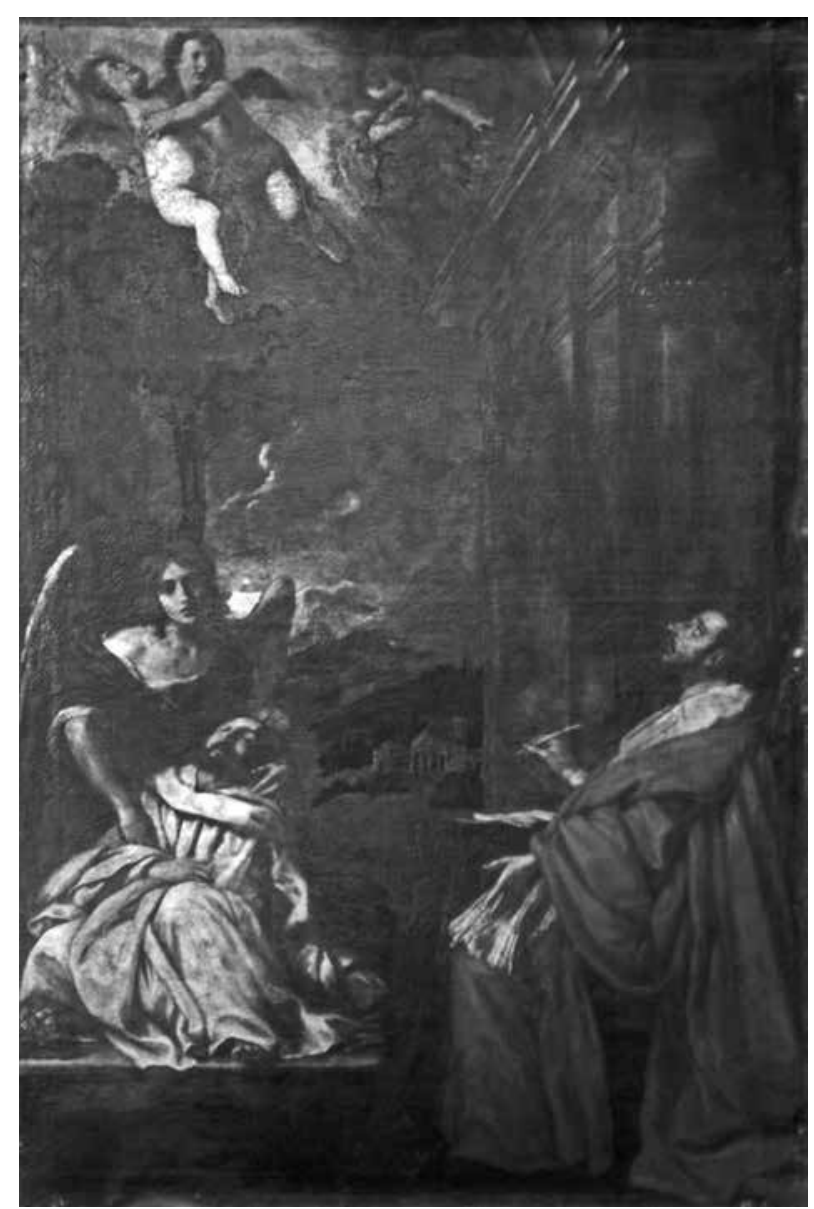

1. Vincenzo Dandini:

Szent Zoerard-András és Borromeo Szent Károly, 1657. Olaj, vászon, $315 \times 197$ cm, Arezzo, Chiesa di Santa Maria in Gradi (fotó: Horváth Zoltán György)

hibás évszámmal. ${ }^{11}$ A kép - amelynek angyalfigurájáról a British Museum gyüjteményében maradt fenn vázlatrajz - Vincenzo Dandini œuvre-jében fontos helyet foglal el: ez a legelső dátummal és szignatúrával jelzett festménye. Mégis csupán rövid, pontatlan leírást nyújt róla a művész életéről szóló egyetlen monográfia, és a kurrens olasz szakirodalomban is akadnak tévedések. ${ }^{12}$ Alessandro del Vita művében Salvi Castelluccinak attribuálja az alkotást, Liletta Fornasarinak a toszkán müvészetről írt 2001-es tanulmányában pedig Santi Andrea e Zoerandro e Carlo Borromeo címen szerepel. ${ }^{13}$

\section{Negyven dió negyven napra}

Vincenzo Dandini képén Szent Zoerard-András az íróasztaláról feltekintő Borromeo Károly előtt jelenik meg, aki mintegy látomást szemlélve tekint a szent életű remetére. Mindezt a művész rendkívül érzékletesen festette meg. ${ }^{14} \mathrm{~A}$ bíborosnak számos hasonló ábrázolása ismert, ahol Krisztust szemléli, ez esetben azonban a zoborhegyi remete áll mintegy példaképként előtte, Pietà-kompozíciókat idéző beállításban. A klerikus életpálya két szélsőséges végletét jelképező és egyben hivatásukat a lehető legmagasabb szinten betöltő férfiak élete számos ponton párhuzamba állítható: egyaránt szigorú önsanyargatással és böjttel zabolázták meg testüket, templomukat erélyesen megvédték a betolakodóktól, valamint mindketten fontos pestisszentnek számítottak a kora újkorban. ${ }^{15}$ Zoerard-András tehát példaképként jelenik meg, és ez két irányban is érvényes. Ahogyan Borromeo Károly számára egy kamalduli életforma szerint élő magyarországi remete követendő eszmény volt, hasonlóképpen a képre tekintő szerzetesek számára is az lehetett. Előttük magának Károlynak a vezeklése is példaképként állhatott.

A kép a szentek életéből vett egy-egy konkrét pillanatot ábrázol. Mór (1000 k.-1070 k.) pécsi püspök Szent Zoerard-András és tanítványa, Benedek életéről 1064-1070 körül írt vitájában olvasható az a jelenet, amikor a kimerültségtől és éhezéstől legyengült remete elájul a zobori erdőben: „Történt egyszer, hogy az agyonerőltetett munkától és szigorú böjtöléstől elcsigázva, testben-lélekben legyengülve aléltan, szinte halálra váltan feküdt a földön. Ekkor egy szép arcú és angyali tekintetű fiú jelent meg előtte, és szekérre téve hazavitte őt cellájába."16 Dandini festményén tehát éppen azt a pillanatot ragadja meg, amikor az angyali tekintetü, gyönyörü ifjú megtalálja az alélt Zoerard-Andrást az erdőben, de még nem tette fel a szekérre, hogy hazavigye zoborhegyi cellájába. A helyszín a környező erdő, mivel a szerzetes a böjti időszakban is, mint rendesen, kiment az erdő egy magányos helyére, fejszét fogva, "hogy ott dolgozzék”. Zoerard-András solitudinem subintravit, ${ }_{17}$ a vadon magányába vonulva tulajdonképpen a kamalduli remetékéhez rendkívül hasonló életmódot folytatott.

Már nem sokkal azután, hogy felöltötte a szerzetesi habitust a zoborhegyi Szent Ipoly-monostorban, megkezdte anakhoréta életmódját. ${ }^{18}$ Mindez megfelel a bencés regulában leírtaknak, amely szerint a szerzetesek négy fajtája közül a második az anakhorétáké, vagyis a remetéké, akik felkészültek a monostorban arra, hogy kivonulhassanak a pusztába az ördög ellen küzdeni. ${ }^{19}$ A kamalduli szerzetesek közül a legkiválóbbaknak szintén lehetőségük nyílik a kolostori közösségtől elvonultan, teljes magányban élniük, hogy a meditációnak és csendes szemlélődésnek, az imának szentelhessék életüket, társaikkal pedig csak évente háromszor találkoznak a nagyobb ünnepeken. Szent Romuald 
(950 k.-1025/1027), a rend alapítója a Szentírás mellett hosszasan tanulmányozta az első egyiptomi remeték életét, a Vitae patrum címú hagiográfiai gyüjteményt, valamint Johannes Cassianus Collationes patrumát, és ezek nyomán igyekezett az általa alapított remeteségekben megvalósítani a klasszikus, sivatagi életforma eszményképét. ${ }^{20}$

Szent Zoerard-András az életszentséget egyéb önsanyargatási módokkal is kiérdemelte. Legendája alapján ábrázolásain leggyakrabban önsanyargatásának eszközeivel: fején faabroncsra kötözött kövekkel, hegyes nádszálakkal kivert fatörzsben ülve, oldalán a húsába is belenövő vezeklőövvel jelenik meg. ${ }^{21}$ Hasonló vezeklési módszereket alkalmaztak egyes kamalduli szerzetesek, így Dominicus (9951060) és Laurentius Loricatus (?-1243) is. ${ }^{22}$ Zoerard ezekkel látható a Martin de Vos (1532-1600) rajza után a németalföldi rézmetsző, Jan Sadeler (15501600 k.) által készített metszeten (2. kép), amely kora újkori reprezentációjának legfőbb mintaképe lett. ${ }^{23}$ Kivételes önsanyargatását jelzi Dandini festményén a lábánál heverő apró zsák is, amely a Fülöp apáttól kapott negyven diót rejti a húsvétot megelőző Szent Negyvennapra böjti eledelül. ${ }^{24} \mathrm{Az}$ utóbbi eseményt vizsgálva már Mór püspök párhuzamot vont Zosimas apát szerzetesi életszabályzatával, amely szerint csak negyven datolyát vehet magához a szerzetes a Szent Negyvennap ideje alatt. ${ }^{25}$ Ugyanakkor a dió Krisztusra való utalás is egyben, a keserü, zöld burok szenvedéseire, a kemény héj a keresztfára, az édes mag pedig Krisztus életet adó, isteni természetére vonatkoztatható. ${ }^{26}$ A motívum jelentőségére mutat a Benedekről, Zoerard-András tanítványáról szóló történet, amely szerint három évvel később pogány rablók gyilkolták meg, mert dús kincseket sejtettek a nagyböjt idején barlangjába viszszaigyekvő remete dióval töltött tarisznyájában. ${ }^{27}$ Karl Stengel 1625-ben megjelent, a bencés rend

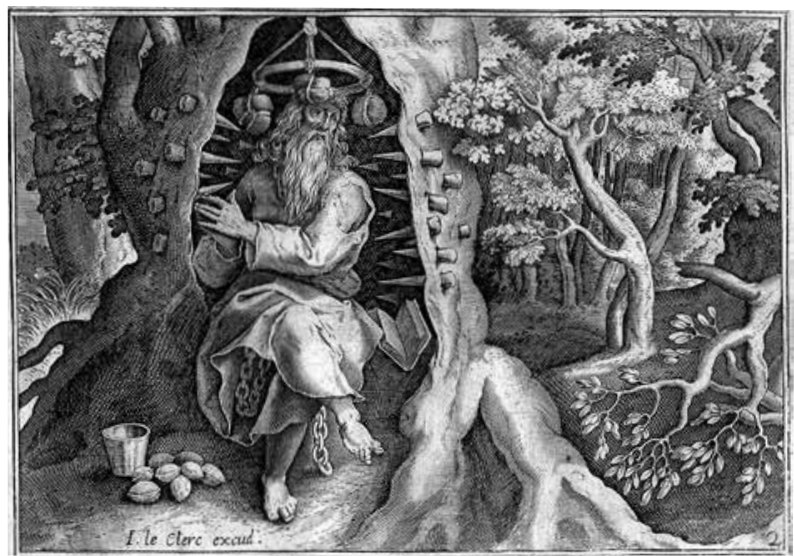

2. Jean le Clerc: Szent Zoerard-András,

1620. Martin de Vos és Jan Sadeler nyomán. Rézmetszet, 19,2×24,1 cm (a szerzó tulajdona) szentjeit összegyűjtő traktátusának illusztrációján éppen ez a jelenet látható, különösképpen azonban - ellentétben ábrázolásaik többségével, valamint a hozzá tartozó szöveggel - itt az önsanyargató Zoerard-Andrással szemben Benedeké a főszerep. ${ }^{28}$ Kevésbé hangsúlyos, ám fontos apró részlet, hogy a Zoerard-András sírja fölé hajló faágra - ezen a helyen imádkozik ugyanis Benedek - az arezzói oltárképről is ismert apró zsákocska van felfüggesztve, noha tartalmát nem látja sem a néző, sem a leendő gyilkos, és jelen esetben szövegutalás sem található mellette. A pogány rabló már lesújtani készül dorongjával, de vajon mit talál majd a negyven dión kívül?

\section{Romuald vagy Zoerard?}

Borromeo Károly tisztelete az arezzói kamalduliak körében azonban korántsem meglepő, mivel biztosan tudjuk, hogy a bíboros maga is járt Camaldoliban, ahol hosszabb időt töltött lelkigyakorlattal. ${ }^{29}$ Jóval bizonytalanabb azonban, hogy pontosan hányszor járt erre, és az anyakolostoron kívül időzött-e a rend más kolostoraiban is. 1579-ben néhány hétre a Sacr'Eremo csendes magányát választotta a kontemplatív elmélkedéshez, egy arezzói kézirat azonban beszámol a kardinális 1564-es látogatásáról a Santa Maria in Gradi monostorában is. ${ }^{30}$ Különösen érdekes lenne ez a dátum azért, mivel 1563-ban zárult le a trienti zsinat harmadik és egyben utolsó szakasza, amelyben tevékeny rész jutott Borromeo Károlynak is. ${ }^{31}$ Azonban nem csak a csendes környezet miatt lett volna kézenfekvő a meditálásra éppen ezt a helyet választania. Anyja révén, aki Medici-lány volt, örökölte a családi tradíciót: a família a 14. század óta szoros kapcsolatban állt a kamalduliakkal, hagyományosan a rend legbőkezübb támogatói közé tartozott. ${ }^{32}$ Amennyiben az 1564-es látogatás valóban megtörtént, úgy nagyszerű magyarázatul szolgálna Károly gyakori ábrázolásaira a templomban. Nem zárhatjuk ki azonban az ellenkezőjét sem, főként mivel Borromeo Károly tisztelete nem csak általánosságban örvendett közkedveltségnek a 17. században, de igen kedvelt szent volt a kamalduliak körében is, köszönhetően Camaldoliban tett látogatásának..$^{33}$

Zoerard-András tisztelete a Santa Maria in Gradiban már kevésbé evidens. Helyi kultuszát ráadásul nem csupán tárgyi emlékek örzik, hanem feljegyzés szól egy kora újkori rítusról is, amelynek keretében a nép a szent ünnepnapján diót vitt a templomba, ahol azt megáldották, hogy ezzel is segítségül hívják a szentet. ${ }^{34}$ Ráadásul nem Vincenzo 
Dandini 1657-ben készült olajfestménye a két szent egyedüli ábrázolása a templomban. Sandro Bellesi 2003-as monográfiájában hivatkozik egy általa 1610 körülre datált festményre, amely a Borromeo Szent Károly és Szent Zoerard-András a halott Krisztus imádása közben címet viseli. ${ }^{35}$ Ez a kép igen szorosan kapcsolódna Dandini múvének témájához. Noha Bellesi állítása szerint a képnek a sekrestyében kellett volna lennie, 2010 augusztusában a helyszínen járva nem láttam a festményt. Létezése szerintem erősen kétséges, mivel a sekrestyében egy Szent Károly és Szent Romuald-oltárkép függött (amely később szintén áthelyezésre került). Ez valóban Borromeo Károlyt ábrázolta, valamint egy kamalduli szerzetest, aki robusztus alkata és beállása alapján inkább attribuálható volt a rendalapító Szent Romualdnak, mintsem Zoerard-Andrásnak. ${ }^{36}$ A templom sekrestyéjében volt azonban egy publikálatlan, 17 . századi olajfestmény is, amelyen a kamalduli habitust viselő, idős, szakállas szerzetes - a felirat szerint - Szent Zoerard-Andrással azonos. Mindezeken túl a Santa Maria in Gradi öt harangjából 1631-ben egy már bizonyosan a magyar szentnek, Zoerard-Andrásnak volt szentelve. ${ }^{37} \mathrm{~A}$ harminc scudóba kerülő harangot Antonio di Martino mester öntötte, akinek nevéhez füződik a Romuald és Szüz Mária tiszteletére készült harangok elkészítése is - az utóbbi kettő nevét balszerencséjére össze is cserélte, amint arról a templom feljegyzései tudósítanak. ${ }^{38}$

Zoerard-Andrásnak három további kivételes ábrázolását is őrzi a templom. A főhajó északi részén két, egymással szemben elhelyezkedő lépcsősor vezet le a kriptába, amelyet Szent Donát mártír, Arezzo védőszentjének tiszteletére szenteltek. ${ }^{39} \mathrm{~A}$ román kori formáit őrző kripta az egyetlen megőrződött része a 11. században épült templomnak, amelyet egy 1590-es tűzvész után Bartolomeo Ammanati (15111592) tervei alapján kellett alapjaitól újjáépíteni. ${ }^{40}$ A tumba subterraneához levezető két lépcsősor elején egy-egy freskóciklus látható. A lépcsforduló északi falán eredetileg egy olajfestmény volt látható, a lejárat fölött és a vele szembeni falon pedig két narratív témájú freskó. A nyugati, vagyis a bejárathoz közelebb fekvő fülke díszítményeinek központi alakja Szent Zoerard-András, a keletié Costacciarói Boldog Tamás (?-1337), sitriai kamalduli szerzetes. Noha Sólymos Szilveszter és Florio Banfi is három freskót említenek, az archív felvételekról egyértelmúen kiderül, hogy a harmadik kép egy falra függesztett olajfestmény volt, amelyet 1995-ben elloptak. ${ }^{41}$ Silvano Pieri a templomról szóló monográfiájában a képeket egy 1680-as évekbeli bencés zarándoklat devóciójának tekinti, valójában azonban a festmények különböző stílusát tekintve nem egy időpontban, hanem különböző periódusban készülhettek. ${ }^{42} \mathrm{Az}$

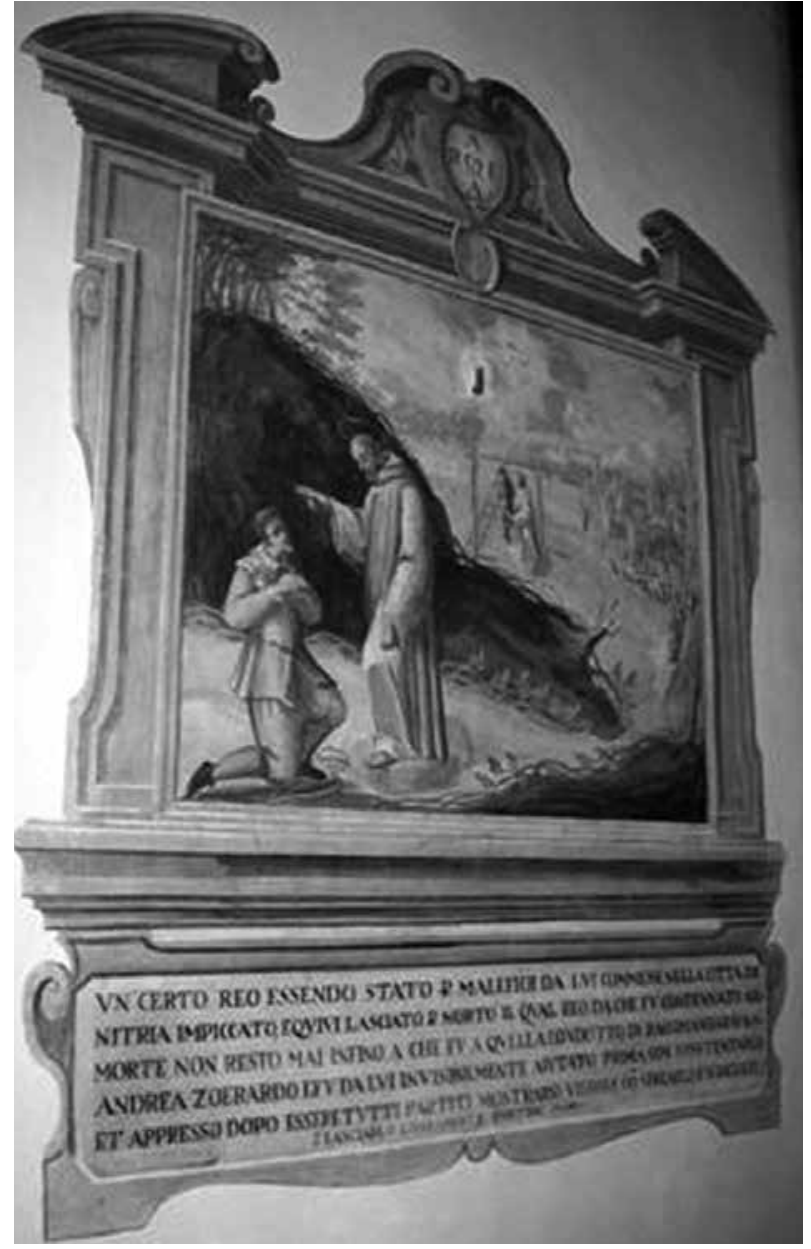

3. Szent Zoerard-András megkegyelmez az akasztott embernek, 1680 körül. Freskó, Arezzo, Santa Maria in Gradi

olajfestményen a remete Dandini képéhez hasonlóan kamalduli habitusban jelent meg, ahogyan egy éles nádszálakkal teletűzdelt odvas fában virraszt, feje körül faabroncsra illesztett kövekkel, nehogy oldalra dőlve elbóbiskoljon. A két falkép közül a nyugati témája Szent Zoerard-András, amint megkegyelmez az akasztott embernek (3. kép), a keletié pedig ahogyan kiűzi az eretnekeket a templomból. ${ }^{43}$ Az utóbbiak olasz nyelvü feliratainak forrását Tommaso Mini 1605-ben megjelentetett, kamalduli szentekről szóló munkájában találtam meg. ${ }^{44}$ A harmadik felirat azonban nem innen származik, amiből arra következtethetünk, hogy a szerzetesek több, különböző forrásból is ismerték Zoerard-András életét.

\section{Zoerard-András tiszteletének eredete Arezzóban}

„Tekintsünk ama híres Anakhorétákra, akik bünbánatukkal megmenekülni igyekeztek a Purgatórium 
kínjaitól. És íme, a nyitrai pusztaságban Zoerarddal találkozunk" - írja Gio Battista Manni 1666-ban megjelent könyvében. ${ }^{45} \mathrm{~A}$ remetét említő számos 17. századi hagiográfiai munka tanúsága szerint személye korántsem volt annyira ismeretlen, mint manapság. Az arezzói kamalduliak oltárának titulusa azonban feltételezésem szerint egyszerűen abból a tévedésből fakad, miszerint saját rendjük tagjának hitték őt. ${ }^{46}$ Ezt támasztja alá a fehér kamalduli habitus, amelyben ábrázolták, valamint tiszteletének további emlékei a templomban és a már említett tumba-lejárat latin nyelvű felirata is. ${ }^{47}$ Utóbbi forrásból derül fény továbbá arra, hogy a szentet lengyel származásúnak vélték, noha nem egyértelmü, hogy a Mór-féle legendaszövegben szereplő „ex terra Poloniensis" Lengyelországot vagy az isztriai Póla vidékét jelölte-e. ${ }^{48}$ Mindez arra utal, hogy kultusza lengyel közvetítéssel érkezhetett Itáliába, miután Jan Długosz (1415-1580) krónikaíró „újra felfedezte" - és egyértelműen a lengyel nemzet javára könyvelte el - Zoerard-Andrásnak a középkor végére elhalványult alakját. ${ }^{49} \mathrm{~A}$ felirat szerint a zobori remetét III. Kallixtusz pápa (1455-1458) kanonizálta, noha ez valójában már 1083-ban megtörtént I. (Szent) László király kezdeményezésére, a néhány évtizeddel később írott Hartvik-legenda tanúsága szerint ráadásul egyenesen a római szentszék kezdeményezésére. ${ }^{50}$ III. Kallixtusznak egyelőre nem ismert semmilyen Zoerard-András személyéhez köthető rendelete, ám a kamalduli szerzetesek hivatkozása mindenképpen érdekes összefüggésbe helyezi a csupán három évig regnáló pápát, akit a török visszaszorítására tett kísérletei nyomán szoros kapcsolatok füztek a magyar királysághoz.

Zoerard-András kultusza a 17. században más kamalduli kolostorokban is virágzott, amelyek közül elsőként kell említenünk a zoborhegyi egykori bencés monostor helyére települt közösségüket, ahonnan szintén fennmaradtak képi ábrázolásai. ${ }^{51}$

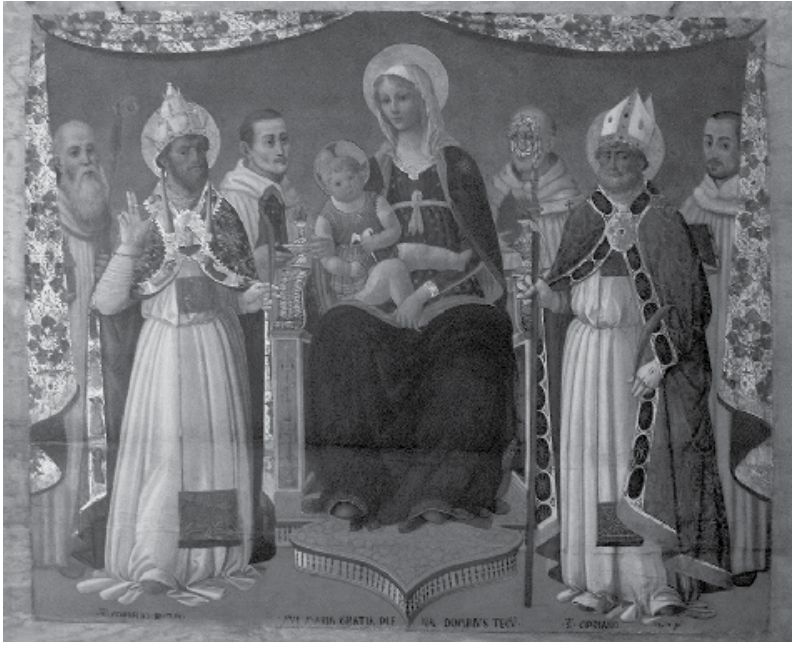

4. Domenico di Michelino: Madonna gyermekkel Szent Kornél, Ciprián, Romuald, Zoerard-András, Bonifác és Makáriosz társaságában, 15. sz. Tempera, fa, $136 \times 172 \mathrm{~cm}$, Volterra, Museo Diocesano di Arte Sacra

Közrejátszhatott tiszteletében az is, hogy személyét Romuald útjához kötötték, aki huszonnégy társával 1008 körül valóban Magyarországra indult. ${ }^{52}$ A szó szoros értelmében persze nem lehet kamalduli missziós tevékenységről beszélni, hiszen Romuald csak 1023 után szervezte meg remeteségét Camaldoliban, másrészt pedig Damiáni Péter minden bizonnyal említette volna a Vita Romualdiban őt is, ha közvetlen kapcsolatban állt volna velük. ${ }^{53}$ Nem egyedülálló példa azonban itáliai tiszteletére a Santa Maria in Gradi sem, hiszen a volterrai Santi Giusto e Clemente-kolostortemplomból is fennmaradt egy Domenico di Michelinónak (1417-1491) attribuált oltárkép, amelyre a 17. században Szent Zoerard-Andrást is ráfestették (4. kép). ${ }^{54}$ Úgy gondolom azonban, hogy Vincenzo Dandini festménye a volterrai képnél jóval személyesebb és elmélyültebb alkotás, amelyen a zoborhegyi remete számára fontos példaadó szerep jut.

\section{JEGYZETEK}

A tanulmány 2011. évi OTDK-dolgozatom átalakított változata. [Absztrakt: Ilkó Krisztina: Vincenzo Dandini (1607-1675) Szent Zoerard-András (Szórád) és Borromeo Szent Károly-oltárképe az arezzói Santa Maria in Graditemplomban. In: Kozári József - Reichmann Angelika szerk.: XXX. Jubileumi OTDK Humán tudományi szekció. (Tartalmi összefoglalók, Eger, 2011. április 18-20.), Eger 2011, 243.]

1 Arezzo, Biblioteca Città di Arezzo, ms. 521. [N. n.]: Chiese e monasteri della diocesi di Arezzo (kézirat, 19. sz.), 173. "A tempo dé Gentili questo era il thempis di Pallade".
2 Susanna Partsch: Vincenzo Dandini. In: Ulrich Thieme - Felix Becker Hrsg.: Allgemeines Künstlerlexikon, Band 24. München-Leipzig 2000, 89-90.

3 Simone De Fraja: Ricordi della Chiesa di Santa Maria in Gradi raccolti da Angelo Pasqui. Atti e Memorie della Accademia Petrarca di Lettere, Arti e Scienze, Nuova Serie, Vo. LIX, LX, Anni 1997-1998, Arezzo 2000, 464. „Adi 10 Decembre 165, Altere - Cod:B: 239, tergo. Ricordo come nel presente anno si è fatto una cappella et altere di Petra prezzo di scudi dugento novanta le sole pietre, lavorate per mano di mastro Jacopo Buonfiglioli e detto altere è posto nella nostra chiesa dalla parte dell'aqua santa sotto 
l'invocazione del glorioso S. Carlo Borromeo e S.Andrea Zoerardo Camaldolense non computati in questa spesa il muratore, i cimenti, i ferramenti che importarono più di 30 scudi."

4 Uo. 465. „Ricordo come in detto giorno et anno fu messo in detto altere la tavola con l'immagine del glorioso S.Carlo e S.Andrea Zoerardo fatta dal Sig.r Vincenzo Bandini (sic!) di Fiorenza per prezzo di scudi ottanta non computate le spese per l'ornamento e mondotta."

5 Archivio di Stato di Firenze. Corporazioni Religiose Sopprese dal Governo Francese. 11, 7. 168v. „Fattura d'un quadro da Altare con l'immagine di S. Carlo e S. Andrea Zoerandro."

6 Silvano Pieri: S. Maria in Gradi di Arezzo, Monastero - Chiesa - Parrocchia. Arezzo 1994, 127.

7 Sólymos Szilveszter: Szent Zoerard-András (Szórád) és Benedek remeték élete és kultusza Magyarországon. Budapest 1996.

8 [N. n.]: Serie degli Uomini i più illustri nella pittura, scultura e architettura. Tomo decimo. Firenze 1774, 165. [N. n.]: Memorie istoriche per servire di guida al forestiero in Arezzo. Firenze 1819, 126.

9 Giovanni Pietro Giussano: Vita di S. Carlo Borromeo prete cardinale. Libro primo. Roma 1610, 7.

10 Jávor Anna: Georg Raphael Donner als Unternehmer, Kollektive Monumentalwerke und Werkstattarbeiten. Jahrbuch der Kunsthistorischen Sammlungen in Wien 98, 1996, 139-148; Szilárdfy Zoltán: Lengyel-magyar szentek. Genealógia és ikonográfia. In: Uő: Ikonográfia Kultusztörténet. Budapest 2003, 254-255; Wehli Tünde: Az 1083-ban kanonizált szentek kultusza középkori müvészetünkben. In: Művelődéstörténeti tanulmányok a magyar középkorról. Szerk. Fügedi Erik. Budapest 1986, 54-56.

11 Florio Banfi: Itáliai magyar emlékek. (Szerk. Sárközy Péter, ford. Kovács Zsuzsa.) Budapest 2007, 43.

12 Sandro Bellesi: Vincenzo Dandini e la Pittura a Firenze alla meta del Seicento. Pisa 2003, 111-112, 181.

13 Alessandro del Vita: Guida di Arezzo. Arezzo 1953, 71. Liletta Fornasari: Arezzo e provincia tra Firenze e Roma. In: Mina Gregori ed.: Storia delle arti in Toscana, Il Seicento. Firenze 2001, 250.

14 Victor I. Stoichita: Visionary Experience in the Golden Age of Spanish Art. Transl. Anne-Marie Glasheen. London 1995, 27-28.

15 Giussano (9. jegyzetben) i. m. 228., 497; Sólymos (7. jegyzetben) i. m. 158., 161.

16 Sólymos (7. jegyzetben) i. m. 36; Maurus: Madzsar Imre szerk.: Vita sanctorum heremitarum Zoerardi confessoris et Benedicti martiris. In: Szentpétery Imre szerk.: Scriptores rerum Hungaricarum tempore ducum regumque stirpis Arpadianae gestarum, 2. Budapest 1937, 358; Ilkó Krisztina: A Boldog Mór által írt Legenda Sanctorum Zoerardi et Benedicti szöveghagyománya a középkor és kora újkor folyamán. In: Bartók Zsófia Ágnes - Dobozy Nóra Emőke - Förköli Gábor et al.: Mü \& Szerző. (Arianna könyvek, 4.) Budapest 2012, 91-100.

17 Scriptores rerum Hungaricarum... (előző jegyzetben) i. m. 358.

18 Viliam Judák: Hviezdy slovenského neba. Nitra $1993,19$.

19 Szent Benedek regulája. Ford. Söveges Dávid. Pannonhalma 2005, 21. „Ezek nem a szerzeteséletnek kezdő nekibuzdulásával, hanem a monostorban való huzamo- sabb próbatétel útján lettek azok. Ezek sok társuk segítségével már megtanultak az ördög ellen küzdeni, és jól felkészülve testvéreik csatasorából magános harcra nyugodtan a pusztába vonulhatnak, és mások támogatása nélkül, puszta kézzel és karral bátran tudnak harcolni Isten segítségével a test és a gondolatok bünei ellen."

20 Pierre Köckert: Romuald von Ravenna und seine Eremiten im Spiegel der Ostmissionierung. Werkzeug der Christianisierung oder selbst gewählte Bürde? München 2010, 11.

21 Friederike Tschochner: Zoerardus (Andreas Swierad) und Benedikt. In: Engelbert Kirschbaum Hrsg.: Lexikon der christlichen Ikonographie, 6 Band. Rom-FreiburgBasel-Wien 1976, 641.

22 Marina Miladinov: Margins of Solitude. Eremitism in Central Europe between East and West. Zagreb 2008, 125; Ilkó Krisztina: Az aszkézis gyakorlatának szélsőséges formái Szent Zoerard-András vitájában. In: Péterfi Bence - Vadas András - Mikó Gábor - Jakab Péter szerk.: Micae Medievales II. Budapest 2012, 39.

23 Caterina Limentani Virdis - Franca Pellegrini - Gemma Piccin: Una dinastia di incisori: i Sadeler. 120 stampe dei Musei Civici di Padova. Padova 1992, 87.

24 Matúš Kučera: Stredoveké Slovensko. Banská Bystrica 2002, 89.

25 Zosimas (lat. Zosimus) története Egyiptomi Mária Szent Sophronios által írt 7. századi életrajzában olvasha-

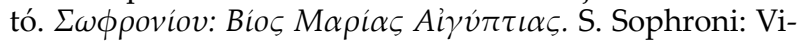
ta Mariae Aegypticae. In: Patrologiae cursus completus. Ed. Jean-Paul Migne. Series Greca, LXXXVII. Paris 1863, 3702-3703; Vita Zoerardi 358.

26 Émile Mâle: Religious Art in France of the Thirteenth Century. (L'Art Religieux du XIII ${ }^{e}$ siècle en France, 1898) London 2000, 30.

27 Tarczai György [Divald Kornél]: Az Árpádház szentjei. Budapest 1930, 21.

28 Carolus Stengelius: Imagines sanctorum ordi Sancti Benedicti tabellis aereis expressae cum eulogiis ex eorundem vitis. [H. n.] 1625, 60-61.

29 Giussano (9. jegyzetben) i. m. 371-372.

30 Arezzo, Biblioteca Città di Arezzo, ms. 521., 176.

31 M. Louise Kenny: Saint Charles Borromeo: A Sketch of the Reforming Cardinal. London 1911, 52-53.

32 Ubaldo Lumini: Camaldoli e la sua storia. Atti e Memorie della Accademia Petrarca di lettere, Arti e Scienze, Nuova Serie, Vol. XXXVII, Anni 1958-64. Arezzo 1965, 458.

33 [N. n.]: Cenni storici intorno al Sacro Eremo di Camaldoli. Arezzo 1859, 48, 126.

34 Sólymos (7. jegyzetben) i. m. 153.

35 Bellesi (12. jegyzetben) i. m. 112.

36 Pieri (6. jegyzetben) i. m. 70-71.

37 De Fraja (3. jegyzetben) i. m. 461-462.

38 Uo.

39 Pieri (6. jegyzetben) i. m. 79-86. „Dicitur consecratum a divo Donato ut est videre in memoria in dieta ecclesia existente."

40 Mario Salmi: La cripta di Santa Maria in Gradi. Atti e Memorie della R. Accademia Petrarca di Lettere, Arti e Scienze. Nuova serie, Vol. XII, I. Semestre, Arezzo 1932, 39-50.

41 A képet 1995-ben lopták el. Don Enrico Gilardoni, a Santa Maria in Gradi jelenlegi plébánosának szíves szóbeli közlése (2010. augusztus). Banfi (2007). 
42 Pieri (6. jegyzetben) i. m. 79; Ilkó Krisztina: Sancte Andrea Zoerarde, serve Dei, defende ecclesiam! Szent Zoerard-András (Szórád) három barokk ábrázolása az arezzói Santa Maria in Gradi-templomban. In: Vidimus enim stellam eius... Szerk. Szávay László. Budapest 2011, 191.

43 Felirataik: $1 .:, \mathrm{Vn}^{\prime}$ certo reo essendo stato maleficii da lvi commessi nella citta di I Nitria impiccato, eqvivi lasciato morto il qval reo da che fv condennato alla I morte, non resto mai infino, a che $\mathrm{fv}$ a qvella condotto, di raccomandarsi a.s. I Andrea Zoerardo e fv dalvi invisibilmente aivtato, prima con sosstentario I et appresso dopo essere tvtti partiti mostrarsi visibili co spiccarlo, e sciolglierlo | e lasciarlo liberamente partire." 2.: „Volendo gl'eretici rovinare la chiesa dedicata a.s. Andrea Zoerardo I et vccidere li cattolici in essa concorsi il detto santo con visibili | fiamme di fvoco visibilmente apparendo. Severamente gli percosse lano I MDLXVIIII nel giorno della festivita sva il di XVI di lvglio."

44 Tommaso Mini: Le vite de Santi Giovanni, e Benedetto, Discepoli del Padre San Romualdo... Fiorenza $1605,20-27$.

45 Gio Battista Manni: Sacro Trigesimo di Varii Discorsi per Aiuto dell' Anime del Purgatorio. Venetia 1666, 105. „.... vedere li famosi Anacoreti, che con le penitenze si studiano di fuggire le pene del Purgatorio. Ed ecco c'incontriamo nel deserto di Nitria Zoerardo."

46 Joannes Bollandus - Godofridus Henschenius - Daniel Paperbochius - Franciscus Baertius... [et al.]: Acta Sanctorum. Iulii. Vols. 9. Antwerpen 1634-1794 (repr. 1965-1970), 331.
47 Ilkó (42. jegyzetben) i. m. 186. „S. Andreas Zoerardus Confessor Polonus monachus camaldulensis. Obiit in Ungaria in monte Ferreo an. 1009. die 16. iulii, in Ecclesia s. Emmerami Martiris sepultus est. Et dum viveret et post mortem miraculis clarus. A Callisto III. Pontifex Maximus in numerum Sanctorum relatus."

48 Boba Imre: Saint Andreas-Zoerard: A Pole or an Istrian? In: Ungarn-Jahrbuch, Band 7, 1976, 65-71; Stanistaw Petrzak: „Terra Poloniensium”, z której pochodził „Zoerardus-Andreas". In: Święty Świerad i jego czasy. Ed. Leszek Migrała. Nowy Sącz 2001, 158-178.

49 Veszprémy László: Royal Saints in Hungarian Chronicles, Legends and Liturgy. In: Lars The Making of Christian Myths in the Periphery of Latin Christendom c. 10001300. Ed. Boje Mortensen. Copenhagen 2006, 219-220.

50 Klaniczay Gábor: Az uralkodók szentsége a középkorban. Magyar dinasztikus szentkultuszok és európai modellek. Budapest 2000, 120, 118-119.

51 Józef Tadeusz Milik: Święty Świerad. Saint Andrew Zoerardus. Roma 1966, 47; Viliam Judák: Svätý Svorad. Patrón mesta Nitry. Nitra 1999, 38.

52 Peter Damian: Life of Saint Romuald of Ravenna. Trans. Nancy Vine Durling. In: Medieval Hagiography: an Anthology. Ed. Thomas Head. London-New York 2001, 309-310.

53 Alberta Piroci Branciaroli: Camaldoli. Il monastero l'eremo e la foresta. Città di Castello 2003, 58.

54 Francesca Pellegrino: 62. Pala d'altare. In: Volterra d'oro e di pietra. A cura di Mariagiulia Burresi - Antonino Caleca. Pisa 2006, 113-114.

\section{THE ST. ZOERARD-ANDREW AND ST. CHARLES BORROMEO ALTARPIECE OF VINCENZO DANDINI IN THE CHURCH OF SANTA MARIA IN GRADI AT AREZZO}

This study introduces ways to unfold the St. Zoerard-Andrew and St. Charles Borromeo Altapiece of Vincenzo Dandini (1607-1675), the gifted pupil of the famous baroque painter, Pietro da Cortona. Created in 1657, it is still housed today in its original position in the Church of Santa Maria in Gradi at Arezzo, in Tuscany. This painting has its own importance in Dandini's oeuvre, not only because it's his first dated and signed work, but also because of the rarity of the imagery of Zoerard-Andrew in Italy.

We can separate two different levels of the image: the Hungarian hermit could be seen as the subject of the cardinal's vision and his role model too. Charles Borromeo was the leading figure of the Council of Trent, and the cardinal archbishop of the Archidiocese of Milan, but had similar fasting and extreme starving practices like Zoerard-Andrew. So Zoerard-Andrew's presence is more interesting in a Camaldolese altarpiece - however they were both Benedictines - than the well-known italian reformator and makes Dandini's work an iconographical challenge.

The altarpiece depicts a scene from the life of St. Zoerard-Andrew derived from the Vita Sancotum Zoerardi et Benedicti (c. 1064) by Bishop Maurus of Pécs, when the hermit in the state of swoon lies in the arms of an angel (iuvenis visionis angelice). St. Zoerard-Andrew, first canonised saint of the Hungarian Kingdom in 1083, had an extremely stiff fasting practice, ate only one nut day-to-day in the forty days of the Lenten period. His bodily selflacerations were the most terrific ways to earn God, he made for himself a wooden crown with stones hanging on four sides and set on an oak-tree trunk surrounded by sharpened canes. Like on Jan Sadeler's etching, he showned with his clever arrangements designed to prevent sleep as his tipical attributes in this period. This essay contributes to find out appointments of Zoerard-Andrew's and St. Charles Borromeo's way of living with the habits of the Camaldolese monks. I mean they were perfect role models for these hermits of the Santa Maria in Gradi. Finally, I demonstrate in my article how could use up their cult in the order's ideology during the Counter-Reformation and how these elements are interwoven in the iconography of the church.

ILKÓ Krisztina művészettörténész / art historian, Budapest, ilkokriszti@gmail.com

Kulcsszavak: Vincenzo Dandini, Szent Zoerard-András, Borromeo Szent Károly, kamalduli rend, Chiesa di Santa Maria in Gradi, ikonográfia, remete / Keywords: Vincenzo Dandini, Saint Zoerard-Andrew, Saint Charles Borromeo, camaldolian order, Chiesa di Santa Maria in Gradi, iconography, hermit 
